\title{
Grapevine Trunk Diseases Management in Vineyards from Central Transylvania
}

\author{
Liliana Lucia TOMOIAGA*, Veronica Sanda CHEDEA \\ Research Station for Viticulture and Oenology Blaj, România \\ *corresponding author: tomoiagaliliana@yahoo.com \\ BulletinUASVM Horticulture 77(1) / 2020 \\ Print ISSN 1843-5254, Electronic ISSN 1843-5394 \\ DOI:10.15835/buasvmcn-hort: 2019.0041
}

\begin{abstract}
Grapevine trunk diseases (GTD) are among the most important diseases reported in vineyards in central Transylvania. On average, up to $5 \%$ of the vineyards are affected by the GTD although there are also vineyards where the incidence of the attack exceeds 15\%. Recent studies show that the importance of pathogens in wood is so great that they are considered limiting factors that affect the stability of the world's vineyards. The main objective of this study is to develop new sustainable management alternatives for the GTD control. For this purpose, an agroecological variant including prophylactic and cultural measures and two treatments with biofungicides based on: Trichoderma atroviride strain 8, Trichoderma atroviride strain B11 and Trichoderma harzianum, were tested. The frequency of the attack of the main four GTD diseases (Esca complex, Phomopsis dieback, Eutypa dieback and Crown gall) on the SCDVV Blaj homologated grapevine varieties, 'Astra', 'Amurg', 'Brumariu', 'Blasius' 'Radames', 'Rubin' and 'Selena', was assessed showing that these had a lower frequency of the symptoms compared with the widely cultivated variety 'Feteasca regala'. Also the effect of training system (Classical versus semi-high Guyot) on GTD is presented. The classical system had decreased the frequency of crown gall and Phomopsis dieback, and the semi-high Guyot system had decreased Eutypa dieback's frequency, indicating that the training system is an important tool of the agroecological system in maintaing the health of grapevine. Biofungicides tested help reduce the symptoms of GTD, but not enough to help reduce the premature death of grapevine.
\end{abstract}

Keywords: Grapevine trunk diseases (GTD), agroecological variant, biopesticides

\section{Introduction}

The grapevine trunk diseases (GTD) are among the most important diseases reported in the vineyards in the center of Transylvania. On average up to $5 \%$ of the established vineyards are affected by GTD; in some places the incidence of the attack exceeds $15 \%$. The attack usually causes the debilitating and gradual drying of the vines with serious consequences for the productivity and longevity of vineyards. Recent studies show that the importance of the pathogens causing GTD is so large that they are considered limitative factors that affect the stability of vineyards worldwide (Bertsch et al., 2013, Úrbaz-Torres, et al., 2014, Fontaine et al., 2016).

Parasites responsible for the production of these diseases are contaminated through the pruning wounds (weeping phenophasis), or through damage caused by frost, hail, manual and mechanical works. It can equally propagate through the infected material used in grafting, or infected rootstocks. Once they penetrate into the wood, they invade the vascular system and emit phytotoxins causing metabolic disturbances. The 
death of the whole plant always occurs when the amount of toxins emitted by the pathogen reaches such a level that the metabolism of the plant is completely disturbed.

The main GTD pathogens detected in the area studied are: Phomopsis viticola, Eutypa lata, Stereum hirsutum, Phellinus igniarius and Agrobacterium tumefaciens the most widespread and damaging pathogen reported in vineyards in the center of Transylvania. Sporadically, there were also identified species as: Phaeomoniella chlamydospora, Phaeoacremonium aleophilum, Botryosphaeria obtusa, Rosellinia necatrix, Armillaria mella (Comsa et al., 2014).

The fact that the GTD pathogens are located inside the wood makes difficult to combat their attack. Practically at the present time it is impossible to eradicate GTD pathogens responsible for the biological decline of vines, instead it is possible to minimize the risks of contamination and to act on the points of pathogens penetration by prophylactic and cultural prevention of attack. Current research is increasingly concerned about the testing of the tolerance of vine varieties as well as the effect of microorganisms used for biological control, especially Trichoderma species (Di Marco et al., 2004).

The main objective of this research theme is to develop new sustainable alternatives for the management of GTD adapted to the specific conditions of vineyards in central Transylvania, in order to limit the enlargement of the attack, by using an agroecologial cultural variant including the cultivation of the indigenous homologated varieties 'Astra', 'Amurg', 'Brumariu', 'Blasius' 'Radames', 'Rubin' and 'Selena' and a proper training system.

\section{Materials and methods}

The experimental plots were located in Blaj, Craciunelu de Jos and Ciumbrud, all belonging to SCDVV Blaj. The plots (2.5/1.75) were cultivated with varieties homologated at SCDVV Blaj: 'Astra', 'Amurg', 'Brumariu', 'Blasius', 'Radames', 'Rubin', 'Selena' and 'Fetească regala' as control variety, trained in classical system with 5 arms and in demi-high Guyot system, and the evaluation have been done in the field conditions of natural infection with main four GTD diseases: Esca complex, Phomopsis dieback, Eutypa dieback and Crown gall.
It has been tested one cultural variant, the agro ecological one, which included prophylactic measures (phytosanitary selection, removing and burning vines with symptoms; burning of the residues resulting after the dormant pruning), cultural measures (grassing between rows with insectary plants, legumes or legumes mixed with grasses, planting shrubs hedges to attract useful wildlife, planting islands with spontaneous vegetation on the outskirts of plots) and 2 bio fungicides treatments based on Trichoderma atroviride strain 8 (2kg/ha), Trichoderma atroviride strain B11 (2.5 kg/ha) and Trichoderma harzianum $(2.0 \mathrm{~kg} / \mathrm{ha})$, applied after the cuts in dry and after the fall of the leaves.

The effectiveness of fungicide treatments was estimated in function of the used product's effectiveness which was related to a standard control product namely, Triumph 40 W6 with an active substance of copper hydroxide with $40 \%$ metallic copper.

The tolerance of vine varieties homologated at SCDVV Blaj to the attack of GTD has been characterized by analysis of the severity of symptoms, based on observations of frequency of the attack (Comsa et al., 2014). The determination of the susceptibility of vine varieties to GTD was made during the whole vegetation period in 20252017. The notation was carried out on varieties, examining a variable number of vines.

The experimental data were analyzed with the program performing one-way analysis of variance (ANOVA), followed by a Fisher protected least significant difference (PSLD) test. $\mathrm{P}$ values lower than 0.05 were considered significant while $\mathrm{p}$ values between 0.05 and 0.1 were considered as tendencies.

\section{Results and discussions}

The increase of vineyard agro ecosystem resistance to GTD pathogens by implementing the agro-ecological variant - including the resistance of varieties - can be a perspective solution for limiting its biological decline produced by GTD. Figure 1 shows the results obtained on testing the tolerance in terms of attack frequency and expressed as \% of vines with symptoms, for indigenous varieties homologated at SCDVV Blaj and taking as a control variety 'Feteasca regala', the most cultivated variety in this region. 


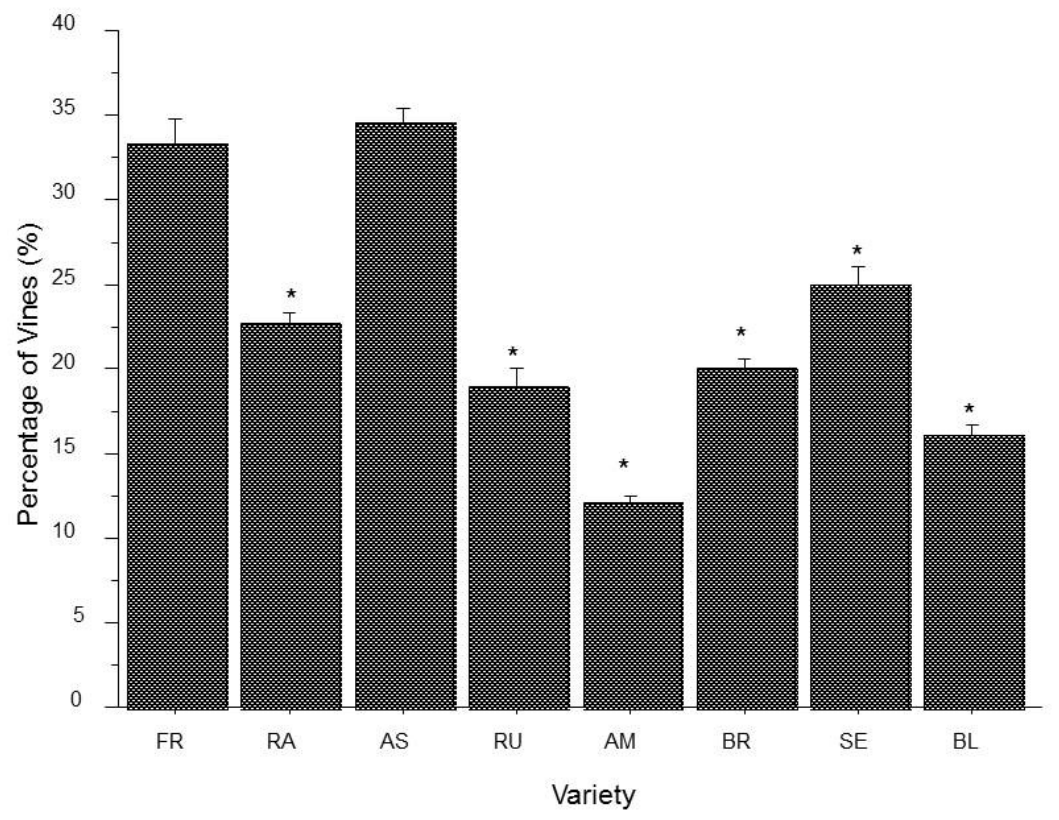

Figure 1. Average percentage of vines with foliar symptoms for the tested varieties between 2015 and 2017 in Tarnave vineyards

( $F R=$ Feteasca regala, $\mathrm{RA}=$ Radames, $\mathrm{AS}=$ Astra, $\mathrm{RU}=$ Rubin, $\mathrm{AM}=\mathrm{Amurg}, \mathrm{BR}=$ Brumariu, $\mathrm{SE}=\mathrm{Selena}, \mathrm{BL}=\mathrm{Blasius}$; *statistically different)

From the observations made during 20152018 it was found that for 'Feteasca regala' variety the frequency of the attack was 33\% of vines and that the 'Astra' variety, was the most affected by the attack of the diseases $(\mathrm{F}=35 \%)$. The other varieties had a significant lower frequency of the attack, 'Selena' with $\mathrm{F}=26 \%$, 'Radames' $\mathrm{F}=23 \%$, 'Rubin' $\mathrm{F}=19 \%$, 'Blasius' $\mathrm{F}=16 \%$ and 'Amurg $\mathrm{F}=12 \%$ (Fig. 1).

Besides taking for culture a GTD resistant variety, prophylactic preventive measures combined with cultural measures, in particular the vine training system, have an important role in limiting the expansion of the attack. Figure 2 presents how the training system affected the frequency of the attack for the four diseases taken in account.

The classical system had decreased the frequency of crown gall and Phomopsis dieback, and the semi-high Guyot system had decreased Eutypa dieback's frequency (Fig. 2), indicating that the training system is an important tool of the agroecological approach in maintaing the health of grapevine.

The last aspect of the agroecological variant was the testing of some biopesticides for limiting the GTD attack and the effectiveness of
Trichoderma atroviride strain 8, Trichoderma atroviride strain B11 and Trichoderma harzianum is shown in Table 1.

Table 1 shows the effectiveness of biopesticids based on Trichoderma atroviride strain 8, Trichoderma atroviride strain B11 and Trichoderma harzianum on the four GTD studied: esca complex, Phomopsis dieback, Eutipa dieback and Crown gall. The effectiveness of fungicide treatments was estimated in function of the used product's effectiveness which was related to a standard control product, namely Triumph 40 W6 with an active substance of copper hydroxide with $40 \%$ metallic copper. The results show that no product was effective for the crown gall and that the best effect was on Eutipa dieback for wich the biopesticide with Trichoderma harzianum was effective and the ones with Trichoderma atroviride strain 8 and Trichoderma atroviride strain B11 were partial effective (Tab. 1). Trichoderma atroviride strain B11 was also effective against Phomopsis dieback and Trichoderma atroviride strain 8 was partially effective against Esca complex (Tab. 1).

\section{Conclusions}

Increasing the immunity of the vine agro ecosystem by implementing the agro-ecological 


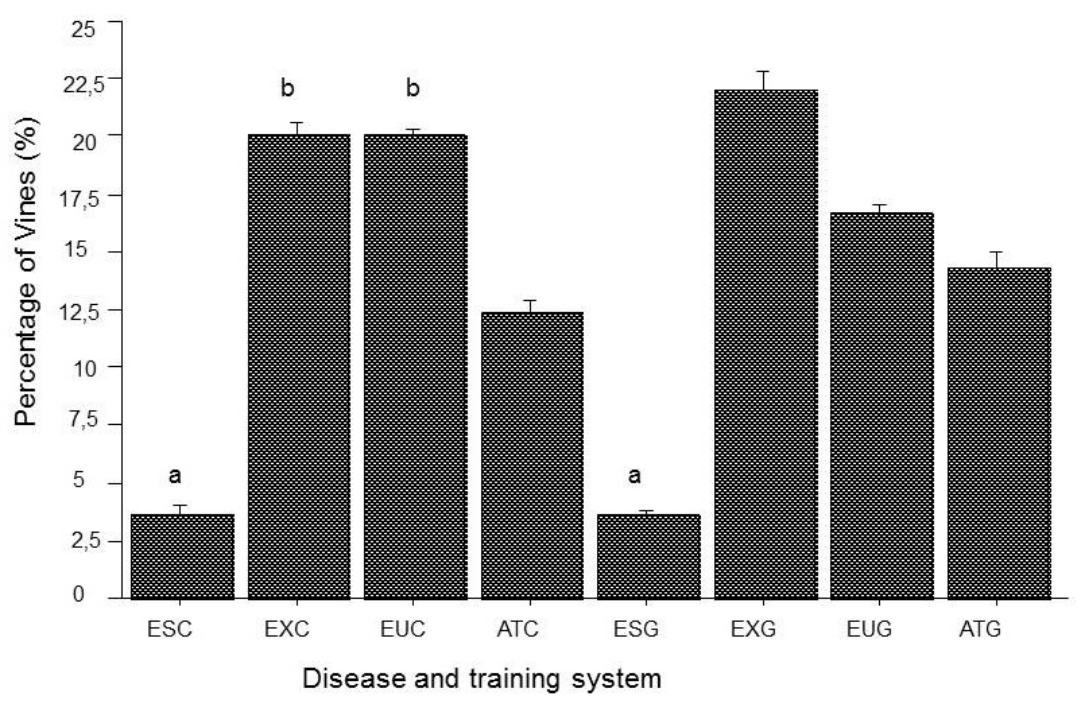

Figure 2. The effect of the training system on the vine decline between 2015 - 2018 in the Central Transylvania vineyards

(ESC $=$ Esca complex in classical system, EXC $=$ Phomopsis dieback in classical system, EUC= Eutipa dieback in classical system, ATC=Crown gall in classical system, ESG=Esca complex in semi-high Guyot system, EXG= Phomopsis dieback in semi-high Guyot system, EUG= Eutipa dieback in semi-high Guyot system, ATC= Crown gall in semi-high Guyot system and ${ }^{\mathrm{a}, \mathrm{b}}$-columns with the same letter are not different statistically)

Table 1. Effectiveness of Trichoderma atroviride strain 8, Trichoderma atroviride strain B11 and Trichoderma harzianum in limiting some of the most important GTD in SCDVV Blaj plantations

\begin{tabular}{ccccc}
\hline Active substance & Esca Complex & $\begin{array}{c}\text { Phomopsis } \\
\text { dieback }\end{array}$ & Eutipa dieback & Crown gall \\
\hline Trichoderma atroviride strain 8 & & & & \\
\hline Trichoderma atroviride strain B11 & & & \\
\hline Trichoderma harzianum & & & \\
\hline
\end{tabular}

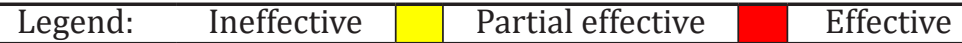

variant including the resistance of varieties can be a solution of perspective in limiting the biological decline produced by GTD. In this direction, the SCDVV Blaj homologated varieties 'Selena' ( $\mathrm{F}=26 \%)$, 'Radames' ( $\mathrm{F}=23 \%)$, 'Rubin' ( $\mathrm{F}=19 \%)$, 'Blasius' ( $\mathrm{F}=16 \%)$ and 'Amurg' ( $\mathrm{F}=12 \%)$ are promising. Prophylactic preventive measures combined with cultural measures in particular the vine training system have a particularly important role in limiting the expansion of the attack, in our case the classical system had decreased the frequency of crown gall and Phomopsis dieback, and the semi-high Guyot system had decreased Eutypa dieback's frequency. Biopesticides based on Trichoderma atoviridae strain 8, Trichoderma atoviridae strain B11 and Trichoderma harzianum applied after training, favors reducing the symptoms of wood diseases, but not enough to guarantee the reduction of the phenomenon of premature death of the hubs. Our study shows that the biopesticide with Trichoderma harzianum was effective against Eutipa dieback and the one Trichoderma atroviride strain B11 was effective against Phomopsis dieback.

\section{References}

1. Bertsch C, Ramírez-Suero M, Magnin-Robert M, Larignon P, Chong J, Abou Mansour E, Spagnolo A, Clément C, Fontaine F (2013). Grapevine trunk diseases: complex and still poorly understood. Plant Pathology, 62(2): 243265.

2. Comsa M, Tomoiaga LL, Popescu DM, Cristea C (2014). Researches regarding the Eutypa Lata lignicole fungus 
manifestation in vineyards from Blaj Wine Centre. Bulletin of University of Agricultural Sciences and Veterinary Medicine Cluj-Napoca. Horticulture, 71(2) : 349-350.

3. Di Marco S, Osti F, Cesari A (2004). Experiments on the control of esca by Trichoderma. Phytopathologia mediterranea, 43(1): 108-115.
4. Fontaine F, Gramaje D, Armengol J, Smart R, Nagy ZA, Borgo M, Rego C, Corio-Costet MF (2016) Grapevine Trunk Diseases. A Review. (1 $1^{\text {st }}$ ed.) Paris: OIV Publications.

5. Úrbez-Torres JR, Haag P, Bowen P, O'Gorman DT (2014). Grapevine Trunk Diseases in British Columbia: Incidence and of the fungal pathogens associated with Esca and Petri diseases of grapevine, Plant Disease, 98(4): 469-482. 